\title{
How Theory of Planned Behavior and Perceived Risk Affect Online Shopping Behavior
}

\author{
Cicilia Sriliasta Bangun ${ }^{1}$, Tessa Handra ${ }^{2}$ \\ ${ }^{1}$ Universitas Esa Unggul, Jl. Arjuna Utara No. 9, Jakarta, Indonesia \\ ${ }^{2}$ Universitas Multimedia Nusantara, Jl. Scientia Boulevard, Tangerang, Indonesia \\ e-mail: cicilia.bangun@esaunggul.ac.id, tessa.handra@lecturer.umn.ac.id
}

\section{To cite this document :}

Bangun, C., \& Handra, T. (2021). How Theory of Planned Behavior And Perceived Risk Affect Online Shopping Behavior.Aptisi Transactions on Management (ATM), 5(2), 169-179.

DOI :

Abstract
Research in the journal that we have made, namely the journal entitled "How Theory of Planned Behavior And Perceived Risk Affect Online Shopping Behavior" has several objectives to analyze the influence of attitudes and subjective norms as well as perceptions of behavior control and people's risk perceptions - people on online shopping intentions and the influence of people on online shopping behavior. two variables influence. First, there are exogenous variables in this study, including attitudes, subjective norms, perceptions of behavioral control, and perceptions of risk. then the second next variable is the endogenous variable, the endogenous variable itself is the intention of the people who shop online and the behavior of the people who shop online. Collecting data in the journal entitled "How Theory of Planned Behavior And Perceived Risk Affect Online Shopping Behavior" was carried out by distributing several questionnaires, and we distributed 100 questionnaires to several e-commerce users who were respondents. By using SEM PLS, the results of this research that have been carried out show that from the five hypotheses developed from the start, only two hypotheses influence online shopping behavior, and there is a subjective norm for online shopping intentions, as well as a perceived risk for purchase intentions.

Keywords: Theory of planned behavior, Perceived risk, Intention to shop online, Behavior to shop online.

\section{Introduction}

The rapid advancement of information technology today has a major influence on the business . Companies must be able to implement information technology in their business in order to be competitive. The important role of technology, especially the internet, currently is using as a tool for business development strategies. The use of the internet has experienced a very significant penetration in the business sector, not only in big companies but also for middle and even low-scale companies. All the companies used the internet to market their products.

Electronic commerce (e-commerce) is a commercial enterprise wherein information generation is used to grow sales, commercial enterprise performance and offer a basis for brand spanking new services and products Through its activities, every enterprise communicates with many different entities: it could be personal or company clients, commercial enterprise partners, suppliers [1]. Electronic commerce is an example of the application of technology that plays an important role in improving the product marketing of a company [2]. E-commerce has risen to become an important technology medium in serving customers, expanding geographic reach, being sensitive to competitive pressures, and reducing operating costs [3]. 
Electronic commerce, usually recognized as E-commerce, is buying and selling in services or products the usage of pc networks, such as the Internet [4]. Electronic trade attracts technologies together with cellular trade, digital budget transfer, deliver chain control, Internet marketing, online transaction processing, digital statistics interchange (EDI), stock control systems, and automatic statistics series systems.

The World Trade Organization defines e-trade as, "e-trade is the production, distribution, marketing, income or shipping of products and offerings with the aid of using digital means". Electronic trade, or e-trade, is the shopping for and promoting of products and offerings on the Internet. Other than shopping for and promoting [5], many human beings use the Internet as a supply of records to examine costs or have a take a observe the modern-day merchandise on provide before creating a buy online or at a conventional store [6]. E-commerce is a buying and selling mechanism using internet technology with cyberspace as a meeting place for buyers and sellers. The implementation of e-commerce in a company becomes the important things to support the successful sales of its product.

E-commerce provides users with the ability to obtain information about goods and services and their purchases anytime, anywhere (no matter where the user is (as long as the user has access to the Internet)), thereby removing barriers related to restrictions. time and space. When purchasing goods or services, users in the electronic field have the opportunity to compare quotations from different sellers based on price, quality, and trust assessment of the seller. Users can personalize and support their purchases based on subjective criteria to determine product choices, such as Convincing sellers to attach great importance to promotional discounts.

Growing numbers of consumers use e-commerce to shop for food products, electronics, transportation (such as gojek / grab / uber, travel) and others. The mostly reason why customer used the e-commerce because of the practical application, transparent cost, detailed location, saving time, the wide range of products, installment payment and attractive promotions. There are various factors that influence consumer's intention to choose e-commerce [7].

The application of e-commerce cannot be separated from the expertise and knowledge of the customer herself in using the internet and computer systems. However, Indonesian awareness of e-commerce is still low due to network limitations, poor telecommunication networks and infrastructure, and financial limitations [8]. This is still an obstacle to increase number of online transaction. In addition, the factor of consumer confidence in e-commerce security can affect someone to shop online.

In explaining the factors that influence consumer behavior to use e-commerce, this study used Theory of planned behavior [9]. Theory of planned behavior (TPB) has supported the predictions of many different people's behaviors. TPB shows that the determinant of behavior is a person's intention. Subjective attitudes and norms influence behavior through intention. Attitude is the overall affective and instrumental evaluation of behavior by individuals. Subjective norms assess social pressure on individuals to do or not perform a behavior. Furthermore, TPB attempts to predict non-willful behavior by including perceived control over behavioral performance as additional predictors of intention and behavior. Perceived behavioral control (PBC) is an individual's perception of the extent to which behavior performance is easy or difficult while maintaining constant motivation.

Small and Medium Enterprises (SMEs) are one of the fields that make a significant contribution to spurring Indonesia's economic growth. SMEs absorb a large number of workers and close to marginalized communities. But they have problem in marketing. Conventional marketing methods require high costs, especially to open a new branch, participating in exhibitions, making and distributing brochures and so on. Using of internet has become a golden opportunity to develop SMEs business and remove the barriers.

Based on the affaimantion above, this study aims to see whether attitudes, subjective norms, perceived behavioral control affect consumer intentions to shop online, and furthermore it will be translated into consumer behavior to shop online. The conceptual framework of this study can be seen in Figure 1. 
Figure 1

Conceptual Framework

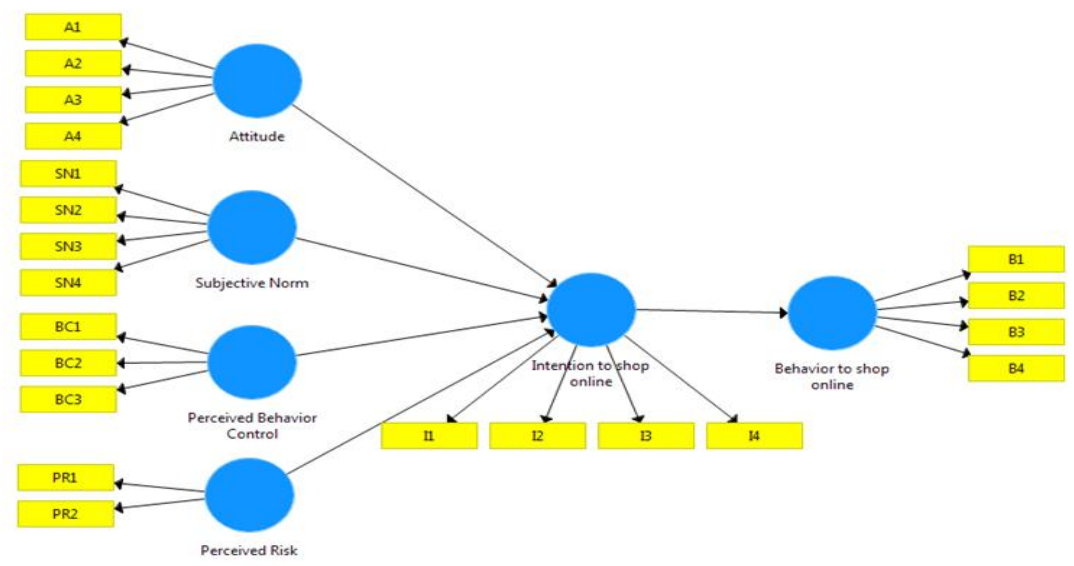

\section{E-Commerce}

Adoption of E-trade gives an exceptional deal of possibility to Small establishments even to advantage more international marketplace get right of entry to, decreasing transaction cost, facilitate get right of entry to capability customers, customization of merchandise and offerings and powerful control of statistics and trade process. Applied and utilized internet optimally in business has increase the competitiveness of the company globally. E-commerce is used as marketing media to offer products or services and accelerate marketing activities. With rapid development of ICT, customers will get better and faster services through e-commerce, flexibility of time on transaction, large selection of products, opportunity to compare prices and quality in a very short time and other benefit [10]. Customers can make order in a simple way and real-time, just sitting inconvenience place and using them [11].

\section{Technology Acceptance Model (TAM)}

Technology recognition fashions and theories were carried out in a wide kind of domain names to recognize and to expect customers' conduct including voting, dieting, own circle of relatives planning, donating blood, the desire of shipping mode, education, consumer's buy behaviors, and pc usage. TAM explains the motivation of customers with the aid of using 3 factors; perceived usefulness, perceived ease of use, and mindset towards use. Therefore, now no longer handiest conduct goal could be contained in TAM however also, leader ideals like perceived usefulness and simplicity of use have a tremendous effect on the mindset of the consumer. These may be decided as an unfavourableness and favourableness towards the machine. Sometimes, different factors referred to as outside variables (consumer training, machine characteristics, consumer participation in layout, and the implementation technique nature) are considered in the TAM model [12].

This theory is used to examine the external factors that motivated a person to accept or refuse an information system and explain the reason so researcher and practitioners can identify the appropriate steps [13]. Perceived usefulness (PU) is described as "the diploma to which someone believes that the usage of a particular [information] gadget could decorate his or her job performance" and perceived ease of use (PEOU) as "the diploma to which someone believes that the usage of a particular [information] gadget could be freed from effort". TAM model empirically can provide an overview of the behavioral aspects of easiness to use the information system according to the customer's expectation [14].

extends the argument that perceived usefulness (PU) and perceived ease of use (PEOU) positively affects the attitudes toward usage (ATU) of a technology. The relationship between these determinants can be illustrated by the model in Figure 2 as suggested by Davis. Both PU and PEOU are influenced by some critical variables

Figure 2.

The Technology Acceptance Model 


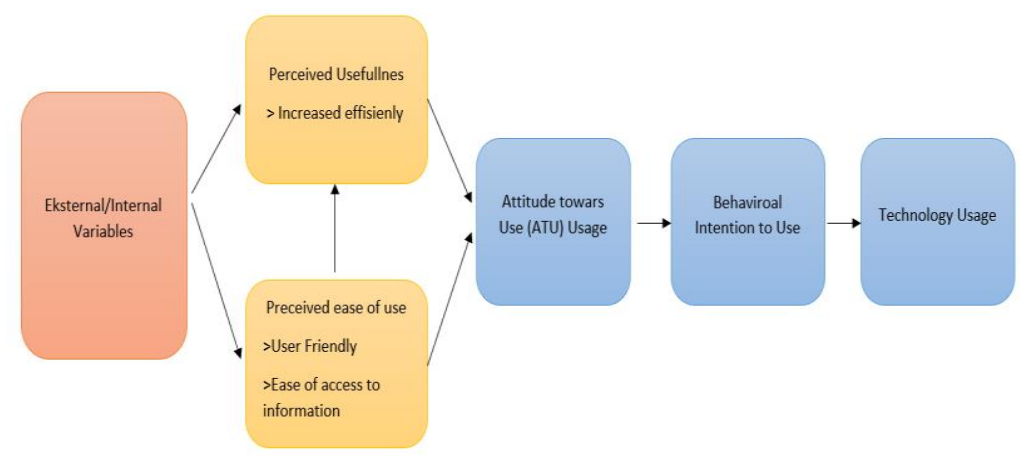

The use of era may be anticipated through competency level (inner variables), which means that having the capabilities and information to apply a gadget will affect its utilization. External variables consist of the ones outside obstacles confronted through customers at some stage in utilization, such as organizational, technological, and social obstacles. Similarly, demographical elements such as gender, pc self-efficacy, and degrees of training (competency) are also used to are expecting technological usage. A positive mindset closer to the era will likely inspire a person to make use of the era.

\section{Theory of Planned Behavior (TPB)}

TPB is an extension of the principle of reasoned action (TRA) to expect a people's purpose to interact in conduct at a particular time and place. Attitudes toward the conduct, subjective norms with appreciation to the conduct, and perceived manipulation over the conduct are normally located to expect behavioral intentions with an excessive diploma of accuracy. According to TPB, an individual's overall performance of sure conduct is decided through his or her intent to carry out that conduct. In different words, TPB puts the individual's purpose to carry out given conduct on the coronary heart of this principle.

A mindset closer to conduct is high quality or bad assessment of appearing that conduct. Attitudes are knowledgeable with the aid of using ideals, norms are knowledgeable with the aid of using normative ideals and motivation to comply, and perceived behavioral manipulate is knowledgeable with the aid of using ideals approximately the individual's ownership of the possibilities and sources had to interact withinside the conduct. Intentions are assumed to seize the motivational elements that influence conduct; they're indicators of ways tough human beings are inclined to try, of ways plenty of an attempt they're making plans to exert, to carry out the conduct. Perceived behavioral manipulate refers back to the belief of manipulating over the overall performance of a given conduct.

Figure 3

Theory of Planned Behavior

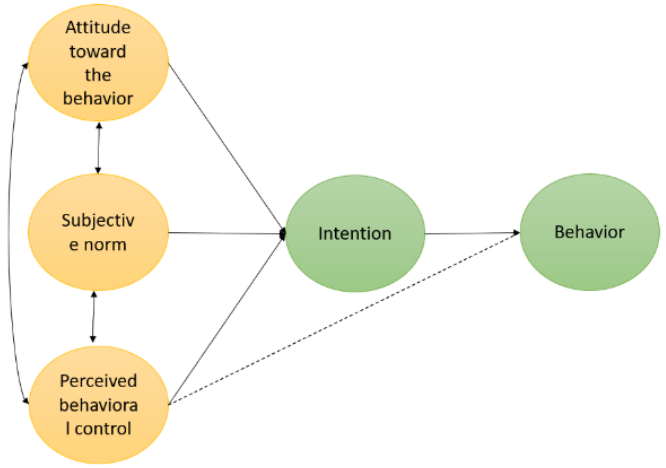

ATM Vol 5, No. 2 July 2021: 169-179 
The idea of deliberate conduct is primarily based totally on the idea that people are rational creatures and use the information systematically. People reflect on consideration on the results in their moves before determining whether or not to have interaction a positive behaviors.

\section{Intention to Shop Online}

Intention to shop online is the tendency of consumers to buy a brand or to take action related to purchase; how likely consumer to switch form a brand to others that measured by the likelihood of consumers to purchase by online [15]. The intention to shop online is a thought that arises because of a feeling of being interested and wanting to have an item or service by online.

\section{Attitude}

Defines attitude as the feeling of the consumer (positive and negative) of an object after evaluating the object [16]. The more objects evaluated, the more attitudes are formed. Attitude has several functions, namely adjustment function, ego defensive, value expression and knowledge. Attitude is decided with the aid of using behavioral ideals (ideals approximately the probability of diverse results) and critiques of how true or awful it might be if the results of the one happened. When an individual undoubtedly appreciates an action, then he's going to do a sure action. Attitude closer to conduct is taken into consideration because of the first variable that impacts conduct intention. Behavioral perception has an effect to perceived behavioral manipulate and subjective norms.

\section{Subjective Norm}

Subjective norm is determined by beliefs about what specific important others think one should do and how much one is motivated to comply with those important others. It is a personal perception that comes from social pressure to do or not do certain behaviors and it can be weighted [17]; recognition of social pressure in showing a special behavior [18].

Subjective norm is based on belief or also called as normative belief, it is a belief to agree or disagree with the thought or attitude of a person or group that affects a person's attitude towards certain behavior. The important social influence of some behaviors is rooted in family, spouse, relatives, colleagues at work and other references related to a behavior.

Social power consists of reward or punishment becomes part of the subjective norm that conveyed by someone to others, how someone likes or admires other people, etc. Normally, a person tends to feel social pressure if he is expected to follow certain behavior and vice versa will not experience social pressure if he is not expected to do something.

\section{Behavior Control}

Behavior control refers to a person's perception of his ability to perform certain behaviors. In other words, behavioral control refers to the extent to which a person feels that performing or not performing certain behaviors is under his concered to control. Behavior control is determined by a number of beliefs about the presence's factors that facilitating the performance of the performed behavior. Behavior is about all human activities, either directly observable or not observable by outsiders. Behavior is a person's response or reaction to external stimuli [19].

Perceived behavioral control is a measure of a person's beliefs about how simple or complex to carry out an action [20]. Behavioral control can also be interpreted as an understanding of how simple or complex to do an action based on previous experience and the obstacles that can be found a solution in doing an action [21]. A person who has subjective attitudes and norms that support certain actions will depend on the support of perceived behavior control he had.

The existence of supporting factors plays an important role in controlling behavior control. Vice versa, the less supporting factors to a person, the more difficult to him to understand the behavior to carry out. A person who has a positive attitude, supported from people around him and less obstacles to carrying out a behavior will have a stronger intention than the person who has positive attitude and supported from people around him with many obstacles.

\section{Perception of Risk}

Sometimes consumers face uncertainty and negative consequences from the purchasing of product or service [22]. Perceived risk is one of the important components in information processing carried out by consumers. Consumers are actively looking for additional information 
when faced with a high-risk purchase. The level of risk in shopping online depends on the perception of consumers in estimating the level of risk that will be experienced when using the internet to shop. Consumers have a higher risk perception when dealing with online purchase compared to offline or in store purchase [23]. Other scholar mentions that the perception of risk is assessed as the level of customer perception of the negative results that may happen when making online transactions [24].

There are three kinds of risks that consumers may experience, which are product risk, transaction risk, and psychological risk. Product risk refers to the uncertainty because the online product purchased does not meet to customer's expectations since the customer does not see or touch by himself [23]. Transaction risk is the risk of uncertainty in payment whether the payment receive to the right person or not. Psychological risk is the fear and worry that come from order process taking place until delivery to the customer. This kind of condition will affect the complexity to make decision. Customers will evaluate the product in detail and compare with others brand. In this study, the authors define perceived risk as the perception or thought about the risk that will be experienced by the customers, uncertainties and the consequences as the impact of online purchase.

\section{The Impact of Attitude to Intention to Use E-commerce}

When costumers assume that using of e-commerce is not important than an attitude is formed so it will make costumers not intend to use e-commerce. Conversely, if consumers assume that using of e-commerce is a must then a positive attitude will be formed. More over, if costumers assume that e-commerce can provide more benefits like easiness to search many kind of products with discount price then the customers will intend to use e-commerce [25].

H1: Attitude has an effect on intention to shop online.

\section{The Impact of Subjective Norms on Intention to Use E-Commerce}

Costumer subjective norms of using e-commerce are formed from the society environment. When most costumers in the society do not use e-commerce and still use direct shopping, a subjective norm is formed and makes costumers unwilling to use e-commerce. The other way around, if society, friends or family recommend using e-commerce and the online transaction process run well then a subjective norm is formed and customers intend to use e-commerce [26].

H2: Subjective norm has an effect on intention to shop online.

\section{The Impact of Perceived Behavior Control to Intention on Shop Online}

When the customers have difficulty using e-commerce then the individual control is formed. This condition will make customers unwilling to use the e-commerce. Vice versa, if the customers experience the easiness using the e-commerce then a positive attitude will be formed [25].

H3: Perceived behavior control has an effect on intention to shop online.

\section{The Impact of Perceived Risk to Intention on Shop Online}

The higher of the perceived risk will make customers avoid using online transaction and the other way around. Risk perception is assumed having negative effect on individual intentions using online stores. Risk perception is an important factor in the assessment of information carried out by customers. Costumers are compelled to seek additional information when dealing with purchasing high-risk products. Low risk perceptions will create high interest in online transaction and of course high risk perception will create low interest using online [27]. The study by [28] concluded that perceived risk has an effect on intention to shop online.

H4: Perceived risk has an effect to purchase intention.

\section{Impact of Intention to Shop Online on Behavior to Shop Online}

Intention to shop online can create behavior to shop online based on interest of the costumers. On the the stage of creating interest of the costumer, they realize that they like certain products and want to own the product from themselves then the belief of the product is positive. This kind of condition will lead to carry out purchasing behavior. Intention to shop online is a variable that effect behavior to shop online [29].

H5: The intention to shop online has an effect on behavior to shop online. 


\section{Rersearch Method}

This study aims to analyze the effect of attitude, subjective norm, perceived behavior control and perceived risk on intention to shop online and their impact on behavior to shop online. The exogenous variables were attitude, subjective norm, perceived behavior control and perceived risk. The endogenous variables are the intention to shop online and the behavior to shop online. This study involves 100 respondents who experienced using e-commerce minimal 3 times in the last 3 months. The respondents consisted of 3 men and 97 women, workers, aged from 21 to 50 years, domiciled in Jakarta. The respondents are requested to fill the questionnaire and analyze using SEM PLS.method.

\section{Result And Analysis Validity Test}

The corrected convergent validity test is declared valid if the loading factor value is greater or equal to 0.3 . While discriminant validity is seen from the AVE value and is declared valid if it is greater than or equal to 0.5 . The results of the convergent validity test can be seen in the following table:

Table 1

Outer Loading

\begin{tabular}{|c|c|c|c|c|c|c|}
\hline & Attitude & Behavior to sh... & Intention to sh... & Perceived Beh... & Perceived Risk & Subjective Norm \\
\hline A1 & 0.944 & & & & & \\
\hline $\mathrm{A} 2$ & 0.956 & & & & & \\
\hline A3 & 0.942 & & & & & \\
\hline $\mathrm{A4}$ & 0.945 & & & & & \\
\hline B1 & & 0.987 & & & & \\
\hline B2 & & 0.988 & & & & \\
\hline B3 & & 0.981 & & & & \\
\hline B4 & & 0.988 & & & & \\
\hline $\mathrm{BC} 1$ & & & & 0.988 & & \\
\hline $\mathrm{BC} 2$ & & & & 0.985 & & \\
\hline $\mathrm{BC} 3$ & & & & 0.984 & & \\
\hline II & & & 0.981 & & & \\
\hline I2 & & & 0.967 & & & \\
\hline B & & & 0.975 & & & \\
\hline 14 & & & 0.964 & & & \\
\hline PR1 & & & & & 0.930 & \\
\hline PR2 & & & & & 0.732 & \\
\hline SN1 & & & & & & 0.967 \\
\hline SN2 & & & & & & 0.983 \\
\hline SN3 & & & & & & 0.979 \\
\hline SN4 & & & & & & 0.968 \\
\hline
\end{tabular}

Source: compiled by the authors

Attitude item has the highest loading factor valued of 0.956 and the lowest value is 0.942 . The item of behavior to shop online has the highest loading factor valued of 0.988 and the lowest value is 0.981 . The item on the intention to shop online has the highest loading factor valued of 0.981 and the lowest value is 0.964 . The item of perceived behavior control has the highest loading factor valued of 0.988 and the lowest value is 0.984 . Item of perceived risk has the highest loading factor valued of 0.930 and the lowest value is 0.732 . The item subjective norm has the highest loading factor valued of 0.983 and the lowest value is 0.967 . Convergent validity test is followed by discriminant validity test by looking at the AVE value. 
Table 2

Average Variance Etracted (AVE)

\begin{tabular}{|l|c|c|}
\hline \multicolumn{1}{|c|}{ Variabel } & AVE & $\begin{array}{c}\text { Cronbach } \\
\text { Alpha }\end{array}$ \\
\hline Attitude & 0,896 & 0,961 \\
\hline Behavior to shop online & 0,972 & 0,990 \\
\hline Intention to shop online & 0,944 & 0,980 \\
\hline Perceived behavior control & 0,972 & 0,986 \\
\hline Perceived risk & 0,700 & 0,601 \\
\hline Subjective norm & 0,949 & 0,982 \\
\hline
\end{tabular}

Source: compiled by the authors

Based on table 2 the AVE value for each variable is greater than 0.5 so that all statement items are valid in a discriminant manner. Instrument reliability testing was tested using Alpha Cronbach analysis. The cronbach's alpha is the average across the coefficients that may be the result of different ways of dividing the scale items. Based on table 2, the alpha-cronbach value for each variable is greater than 0.6 , so it can be concluded that the statement items for each variable are reliable.

\section{Hypothesis Test}

The following table shows the results of hypotheses test:

Table3

Summary of The Result of Hypothesis Test

\begin{tabular}{|l|r|r|r|r|r|}
\hline & Original Sample ... & Sample Mean (.. & Standard Devia... & T Statistics $(\mid$ O... & P Values \\
\hline Attitude -> Int... & 0.263 & 0.269 & 0.114 & 2.304 & 0.022 \\
\hline Intention to sh... & 0.965 & 0.966 & 0.007 & 140.604 & 0.000 \\
\hline Perceived Beha... & 0.512 & 0.478 & 0.172 & 2.977 & 0.003 \\
\hline Perceived Risk ... & -0.017 & -0.015 & 0.031 & 0.538 & 0.591 \\
\hline Subjective Nor... & 0.187 & 0.215 & 0.176 & 1.068 & 0.286 \\
\hline
\end{tabular}

Source: compiled by the authors

Based on table 3 , the p-value for hypothesis 1 is $0.022<0.05$, means that there is an effect of attitude on intention to shop online. The p-value for hypothesis 2 is $0.286>0.05$, which means that there is no influence of subjective norm on intention to shop online. The $p$-value for hypothesis 3 is $0.003<0.05$, which means that there is an effect of perceived behavior control on intention to shop online. The $p$-value for hypothesis 4 is $0.591>0.05$, which means that there is no effect of perceived risk on intention to shop online. And the last, the p-value for hypothesis 5 is $0.000<0.05$, which means that there is an effect of intention to shop online on behavior to shop online. The following is the output image from Smart PLS as seen on Figure 4. 


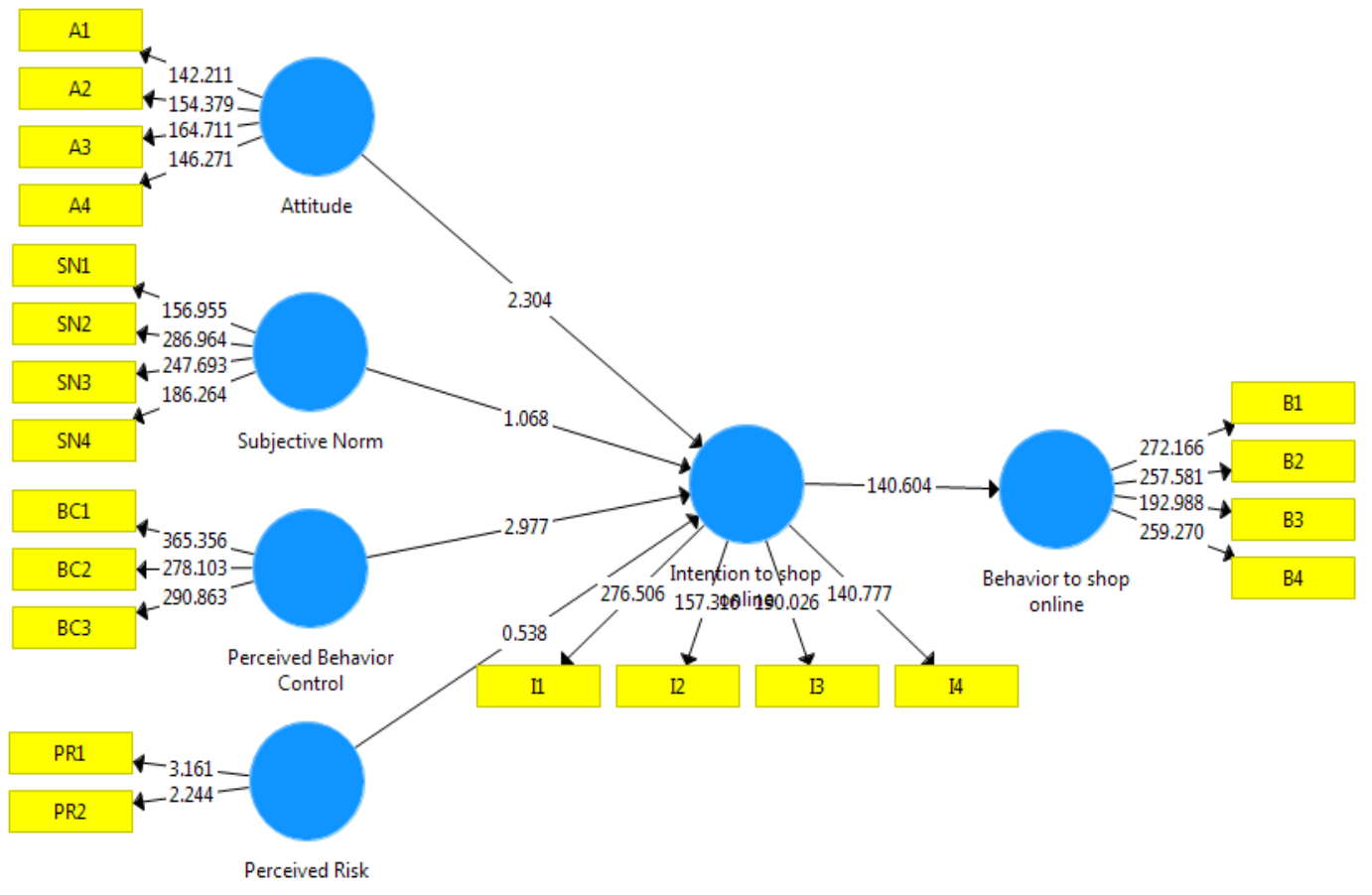

Figure 4. Output of Smart PLS

\section{Conclusion}

Based on the analysis, the study showed that from 5 hypothesis, only 3 hypothesis are accepted and 2 hypothesis are rejected. Attitude and perceived behavior control have effect on intention to shop online; intention to shop online also has effect on behavior to shop online. This result support previous research conducted.

According to this study, subjective norm has no affect on intention to shop online. The responden of this study are the person who had experienced on using e-commerce at least 3 times on the last 3 months and mature person. They might have good experienced using ecommerce so they did not consider the opinions of the society on intention to shop online, in other words they have ability to make decision wheather using e-commerce or not. This can explain why subjective norm had no effect on intention to shop online does not support Garcia's studied that conducted on 2020.

This study also showed that perceive risk has no effect on intention to shop online and does not support the result of research conducted. The experienced customers may have ability to minimize risk by seeking more information before make decision to buy that product especially when dealing with high risk product. Perception of risk is one of the important components in information processing carried out by costumers.

Respondents of this study are adults and had experienced on shop online, it is advisable to conduct research with younger respondents with various backgrounds to get another insight.

\section{REFERENCES}

[1] M. Išoraitè and N. Miniotienè, "Electronic commerce: Theory and practice," 2018.

[2] T. Hariguna, M. Yusup, and A. Priyadi, "The Transaction Optimization Of Color Print Sales Through E-Commerce Website Based On Yii Framework On Higher Education," Aptisi Trans. Technopreneursh., vol. 1, no. 1, pp. 1-10, 2019.

[3] E. Depiana and H. Hartelina, "Marketing Service on Customer Satisfaction of Yamaha Motorcycles at PT Ramarayo Perdana Karawang," Aptisi Trans. Manag., vol. 5, no. 1, pp. 11-19, 2021. 
[4] U. Rahardja, T. Hariguna, and W. M. Baihaqi, "Opinion mining on e-commerce data using sentiment analysis and k-medoid clustering," Proc. - 2019 12th Int. Conf. Ubi-Media Comput. Ubi-Media 2019, pp. 168-170, 2019, doi: 10.1109/Ubi-Media.2019.00040.

[5] D. Ahmad, H. D. Ariessanti, and K. Awaliyah, "Implementation of E-Commerce Website to Increase Online Sales of Case Study of Baby Wise BSD Tangerang," Aptisi Trans. Manag., vol. 1, no. 1, pp. 11-16, 2017.

[6] A. G. Khan, "Electronic commerce: A study on benefits and challenges in an emerging economy," Glob. J. Manag. Bus. Res., 2016.

[7] E. Erlina and D. Hermawan, "Marketing Mix on Customer Loyalty at Coffee Shop in Bandung," Aptisi Trans. Manag., vol. 5, no. 1, pp. 89-96, 2021.

[8] E. H. Yindi, I. Maumoh, and P. L. Mahavile, "Exploring the role of Awareness, Government Policy, and Infrastructure in adapting B2C E-Commerce to East African Countries," arXiv Prepr. arXiv2102.11729, 2021.

[9] M. T. Toukabri and S. A. Ettis, "The Acceptance and Behavior Towards E-Insurance," Int. J. E-bus. Res., vol. 17, no. 2, pp. 24-39, 2021.

[10] L. T. Khrais and A. M. Alghamdi, "The Role of Mobile Application Acceptance in Shaping E-Customer Service," Futur. Internet, vol. 13, no. 3, p. 77, 2021.

[11] B. Taneja, "The Digital Edge for M-Commerce to Replace E-Commerce," in Emerging Challenges, Solutions, and Best Practices for Digital Enterprise Transformation, IGI Global, 2021, pp. 299-318.

[12] H. Taherdoost, "A review of technology acceptance and adoption models and theories," Procedia Manuf., vol. 22, pp. 960-967, 2018.

[13] P. J. Ågerfalk and F. Karlsson, "Theoretical, Empirical, and Artefactual Contributions in Information Systems Research: Implications Implied," Adv. Inf. Syst. Theor. Ration. Process., pp. 53-73, 2021.

[14] S. Sayyida, S. Hartini, S. Gunawan, and S. N. Husin, "The Impact of the Covid-19 Pandemic on Retail Consumer Behavior," Aptisi Trans. Manag., vol. 5, no. 1, pp. 79-88, 2021.

[15] F. Hussein and H. Hartelina, "After Sales Service For Smartphone Iphone To Customer Loyalty," Aptisi Trans. Manag., vol. 5, no. 1, pp. 62-72, 2021.

[16] I. Kim, H. J. Jung, and Y. Lee, "Consumers' Value and Risk Perceptions of Circular Fashion: Comparison between Secondhand, Upcycled, and Recycled Clothing," Sustainability, vol. 13, no. 3, p. 1208, 2021.

[17] D. C. Doanh, "The moderating role of self-efficacy on the cognitive process of entrepreneurship: An empirical study in Vietnam," Explor. Link Between Entrep. Capab. Cogn. Behav., p. 147, 2021.

[18] V. Scoppa, "Social pressure in the stadiums: Do agents change behavior without crowd support?," J. Econ. Psychol., vol. 82, p. 102344, 2021.

[19] R. McGarva, "Striving for Homeostasis: Balancing the Inclusion of Students with an Emotional/Behavioral Disorder," 2021.

[20] S. A. Bin-Nashwan, H. Abdul-Jabbar, S. F. Dziegielewski, and S. A. Aziz, "Moderating effect of perceived behavioral control on Islamic tax (zakah) compliance behavior among businessmen in Yemen," J. Soc. Serv. Res., vol. 47, no. 2, pp. 292-302, 2021.

[21] S. I. Rusu and C. M. A. Pennartz, "Learning, memory and consolidation mechanisms for behavioral control in hierarchically organized cortico-basal ganglia systems," Hippocampus, vol. 30, no. 1, pp. 73-98, 2020. 
[22] T. Handra and F. Sutisna, "PENGARUH SOCIAL IDENTITY, EWOM, PERCEIVED RISK, DAN TRUST TERHADAP PURCHASE INTENTION DAN DAMPAKNYA TERHADAP PURCHASE DECISION PADA E-COMMERCE," J. Bina Manaj., vol. 9, no. 2, pp. 126145, 2021.

[23] S. Sharma, G. Singh, and S. Pratt, "Modeling the Multi-dimensional Facets of Perceived Risk in Purchasing Travel Online: A Generational Analysis," J. Qual. Assur. Hosp. Tour., pp. 1-29, 2021.

[24] A. Esmaeili, I. Haghgoo, V. Davidavičienè, and I. Meidutè-Kavaliauskienè, "Customer Loyalty in Mobile Banking: Evaluation of Perceived Risk, Relative Advantages, and Usability Factors," Eng. Econ., vol. 32, no. 1, pp. 70-81, 2021.

[25] N. Peña-García, I. Gil-Saura, A. Rodríguez-Orejuela, and J. R. Siqueira-Junior, "Purchase intention and purchase behavior online: A cross-cultural approach," Heliyon, vol. 6, no. 6, p. e04284, 2020.

[26] V. H. Pradeep, V. T. Amshala, and B. R. Kadali, "Does perceived technology and knowledge of maintenance influence purchase intention of BEVs," Transp. Res. Part $D$ Transp. Environ., vol. 93, p. 102759, 2021.

[27] A. Shankar and S. Jain, "Factors affecting luxury consumers' webrooming intention: a moderated-mediation approach," J. Retail. Consum. Serv., vol. 58, p. 102306, 2021.

[28] S. A. Qalati, E. G. Vela, W. Li, S. A. Dakhan, T. T. Hong Thuy, and S. H. Merani, "Effects of perceived service quality, website quality, and reputation on purchase intention: The mediating and moderating roles of trust and perceived risk in online shopping," Cogent Bus. Manag., vol. 8, no. 1, p. 1869363, 2021.

[29] H. Islam, C. Jebarajakirthy, and A. Shankar, "An experimental based investigation into the effects of website interactivity on customer behavior in on-line purchase context," $J$. Strateg. Mark., vol. 29, no. 2, pp. 117-140, 2021. 